\title{
QUALITY POTENTIAL OF SOME NEW PEAR CULTIVARS - HOW TO OBTAIN FRUIT OF THE BEST SENSORY CHARACTERISTICS?
}

\author{
Dorota KONOPACKA ${ }^{1 *}$, Krzysztof P. RUTKOWSKI ${ }^{1}$, Dorota E. KRUCZYŃSKA ${ }^{2}$, \\ Anna SKORUPIŃSKA ${ }^{1}$, Witold PŁOCHARSKI ${ }^{1}$ \\ ${ }^{1}$ Department of Fruit Storage and Processing \\ ${ }^{2}$ Department of Pomology and Nursery \\ Research Institute of Horticulture \\ 96-100 Skierniewice, Konstytucji 3 Maja 1/3, Poland
}

Received: January 1, 2014; Accepted September 9, 2014

\begin{abstract}
The eating quality of nine new pear cultivars grown in Poland was investigated in 2008-2011. Fruits of two summer cultivars: 'Alfa' and 'Radana', as well as late season varieties: 'Hortensia', 'Dicolor', 'Concorde', 'Uta', 'Xenia', 'Erika' and 'Verdi' were compared to fruits of 'Clapp's Favorite' and 'Conference', which were taken as cultivars of reference. Fruits of all cultivars were harvested from the Experimental Orchard of the Research Institute of Horticulture at the commercial maturity stage and stored at $+2.5^{\circ} \mathrm{C}$ or $-0.5^{\circ} \mathrm{C}$ in a normal atmosphere (NA) or at $-0.5{ }^{\circ} \mathrm{C}$ in a controlled atmosphere (CA) $\left(0.7 \% \mathrm{CO}_{2}: 2 \% \mathrm{O}_{2}\right)$ for 6 to 16 weeks. At the end of storage, the fruits of each cultivar were subjected to an individual ripening schedule at $18{ }^{\circ} \mathrm{C}$ (up to 14 days), which generated samples of diversified quality attributes. Based on instrumental analyses and descriptive sensory assessment the quality attributes of each cultivar were examined. The gathered data on the dynamics of quality attribute changes during the ripening stage confirm that each new cultivar needs an individual strategy during storage and ripening in order to maximise their specific sensory attributes to increase potential market value. The obtained data leads to the conclusion that 'Xenia' and 'Concorde' fruits have the biggest chance to fulfil consumer expectations, as they were appreciated more than the reference 'Conference' cultivar. Among the others also 'Hortensia', 'Verdi' and 'Dicolor' were scored higher than 'Conference', but their advantages were not so evident.
\end{abstract}

Key words: pear cultivars, ripening behaviours, firmness, sensory attributes, eating quality

\section{INTRODUCTION}

Although pear growing in Poland has a long tradition, fruit consumption is still at a low level. According to the Central Statistical Office (Nosecka 2012), the consumption of pears between 20082011 on average $1.01 \mathrm{~kg}$ per person per year, being much lower, even than the consumption of plums $(1.86 \mathrm{~kg})$, which are eaten primarily as a seasonal fruit. During the same period, the consumption of apples equated to $14.85 \mathrm{~kg} /$ person/year. The main reasons for such low consumption of pears are relatively high prices and problems with purchasing fruits of a predictable and stable eating quality, which meets consumers' expectations.
The main quality problems are related to the improper storage and ripening of pears, which are typical climacteric fruits, however, their ripening process and response to storage conditions (Błaszczyk 2010; Ma \& Chen 2003; Wawrzyńczak et al. 2006; Wawrzyńczak et al. 2008a; Wang \& Sugar 2013) are substantially different from that of apples, representing the same ripening pattern. Pears are also much more sensitive to physiological disorders during storage than apples. In literature it is possible to attain some information on the effect of pre- and post-harvest factors on the quality and storability of pears and their susceptibility to physiological disorders (Hardenburg et al. 1986; Streif et al. 2003; Sugar 2007). The next difficulties are re- 
lated to highly dynamic pear quality changes. The information concerning quality characteristics and in particular, the sensory appraisal of pears is inadequate, as the available data is mainly focused on singular cultivars that are promoted by local societies (Predieri \& Gatti 2008, 2009; Salvador et al. 2007; Pinto et al. 2008).

Irrespective of the above mentioned problems, interest in pear consumption has increased recently, mainly due to their specific nutritional properties, and in particular high potassium and dietary fibre content, and rare, when compared to apple, allergic reactions. These medical facts seem to create a good opportunity to encourage consumers to increase pear consumption, especially as a lot of new attractive cultivars available within breeding programs can really satisfy the gustatory preferences, of even the most demanding consumer. Although numerous promising cultivars are available, there is little information describing the relation between fruit quality attributes and sensory properties (Błaszczyk \& Buczek 2002; Wawrzyńczak et al. 2008b; Błaszczyk 2011; Steyn et al. 2011). The lack of information on both ripening behaviour and consumer acceptance presents a serious barrier for popularisation of new or lesser known pear cultivars, which in turn restricts pear fruit diversity, which could favour higher pear consumption.

The aim of the presented study was to characterise ripening behaviour and eating quality of new pear cultivars grown in Poland. Taking into consideration individual ripening dynamics of the investigated cultivars, efforts were made to establish the time needed for obtaining fruit of the best sensory quality after certain storage conditions. A "quality map" of perceived sensory characteristics for fruits at their optimal ripening stage was formulated.

\section{MATERIALS AND METHODS}

\section{Materials}

As experimental material, nine new pear cultivars grown in Poland were chosen; two early ripening and seven late season cultivars. Among early ripening (summer) cultivars 'Alfa' and 'Radana' were analysed and compared to 'Clapp's Favorite', which was used as a standard. Late season (fall/winter) cultivars were: 'Hortensia', 'Dicolor', 'Concorde', 'Uta', 'Xenia', 'Erika', 'Verdi', with 'Conference' as the point of reference.

All fruits for the experiment were harvested at commercial maturity stage at the Experimental Orchard in Dąbrowice, belonging to the Research Institute of Horticulture in Skierniewice (formerly Research Institute of Pomology and Floriculture). The date of picking was established based on firmness measurements and a starch index, made on representative samples of pears taken from the orchard. The dates of harvest in successive seasons are presented in Table 1. The following day flesh firmness (FF), total soluble solids (TSS), titratable acidity (TA) and starch index (SI) were measured in 15 fruits.

Table 1. Harvest date in consecutive seasons

\begin{tabular}{lcccc}
\hline \multicolumn{1}{c}{ Seasons: } & 2008 & 2009 & 2010 & 2011 \\
\hline $\begin{array}{l}\text { 'Clapp's } \\
\text { Favorite' }\end{array}$ & Aug-20 & Aug-24 & Aug-23 & Aug-17 \\
\hline 'Alfa' & Aug-04 & Aug-07 & Aug-09 & Aug-08 \\
\hline 'Radana' & Aug-04 & Aug-07 & Aug-09 & Aug-08 \\
\hline 'Conference' & Sept-12 & Sept-14 & Sept-08 & Sept-14 \\
\hline 'Hortensia' & Sept-19 & Sept-14 & Sept-16 & Sept-05 \\
\hline 'Dicolor' & Sept-22 & Oct-02 & Sept-22 & Sept-16 \\
\hline 'Concorde' & Oct-03 & Sept-25 & Sept-22 & Sept-14 \\
\hline 'Uta' & Sept-29 & Sept-25 & Sept-21 & Sept-16 \\
\hline 'Xenia' & Oct-02 & Sept-30 & Oct-02 & Sept-21 \\
\hline 'Verdi' & - & Sept-25 & Sept-16 & Sept-14 \\
\hline 'Erika' & - & Sept-25 & Sept-21 & Sept-16 \\
\hline
\end{tabular}

Additionally, the Streif' Index was calculated using the following formula: $\mathrm{FF} /(\mathrm{TSS} * \mathrm{SI})$. Fruits were stored at $+2.5{ }^{\circ} \mathrm{C}$ or $-0.5{ }^{\circ} \mathrm{C}$ in air (NA) or at $-0.5{ }^{\circ} \mathrm{C}$ in a controlled atmosphere $\mathrm{CA}(0.7 \%$ $\mathrm{CO}_{2}: 2 \% \mathrm{O}_{2}$ ) for 6 or 8 weeks (short storage version) or for 10 or 16 weeks (long storage version) (Table 2). During the experiment (2008-2012) each cultivar was tested at least 3 times. 
Table 2. The schema of cold storage conditions before ripening experiment

\begin{tabular}{lcccccc}
\hline \multirow{2}{*}{ Group of cultivars } & \multicolumn{3}{c}{ Short storage } & \multicolumn{3}{c}{ Long storage } \\
\cline { 2 - 7 } & Atmosphere & Temperature $\left({ }^{\circ} \mathrm{C}\right)$ & $\begin{array}{c}\text { Time } \\
(\text { weeks) }\end{array}$ & Atmosphere & Temperature $\left({ }^{\circ} \mathrm{C}\right)$ & $\begin{array}{c}\text { Time } \\
(\text { weeks })\end{array}$ \\
\hline Summer & NA & +2.5 & 6 & NA & -0.5 & 10 \\
Late (fall/winter) & NA & -0.5 & 8 & CA & -0.5 & 16 \\
\hline
\end{tabular}

\section{Ripening scheme}

On removal from storage, the fruits of each cultivar were subjected to an individual ripening schedule at $18{ }^{\circ} \mathrm{C}$ (up to 14 days), which generated samples of diversified quality attributes. The ripening time was determined during the first year of the experiment, for each individual cultivar as well as for short and long storage options. Two weeks before the end of the planned storage time (according to Table 2) a batch of 10 fruits was removed from cold storage and placed in the ripening room (at $18{ }^{\circ} \mathrm{C}$ ) and every second day fruits were screened for their sensory attributes. Based on the observations, for each combination a 5-point ripening schema for fruit ripening was fixed. Each given day before the planned term of quality assessment 10 pears were moved from cold storage into the ripening room. Finally on the date of the analysis 5 samples varying in ripening degree were available and fruits of different quality attributes were compared during the same session. In the case, when quality diversification was not satisfactory, the following season's ripening schema was adjusted.

\section{Quality characteristic of fruits during ripening}

The quality assessment of stored pears included both instrumental measurements and sensory analysis. An experimental sample of each cultivar representing storage treatment and fruit ripeness stage consisted of 10 fruits. Their firmness (in N) was measured by penetrometric method using Instron 4303 with Magness-Taylor probe of $8.0 \mathrm{~mm}$ diameter. Soluble solids content was estimated simultaneously by refractometric method (\%). Then a small piece from each fruit was cut to prepare a sample for titratable acidity determination, which was measured with potentiometric method by titration to $\mathrm{pH} 8.1$ end point and calculated as citric acid content (\%).

The same fruits were used to prepare samples for sensory analysis. Pear quarters were served in individual plastic containers covered with a lid and assessed using the scaling-profiling method. The expert panel consisted of 10 judges recruited from the staff of the Research Institute of Horticulture, trained and having longstanding experience in sensory assessment of fresh and processed products. Qualitative traits such as aroma (sour, pear, sweet, grass, off), texture (crispness, hardness, crunchiness, flesh consistency, juiciness, stone cell sensation, overall texture quality) and taste (sweet, sour, astringent, pear flavour) were evaluated. Additionally, the overall quality was determined as the sensory impression of the balance and harmony of all the attributes and their interaction, which can be considered a reliable indicator of potential buyers' perception (Konopacka et al. 2006). Each attribute was rated on a continuous linear scale with anchor points at each end, marked as 0 and 100 points, where 0 denotes lack/low intensity or inappropriate harmonization of evaluated characteristic, and 100, high intensity or very good harmonization of the evaluated attribute. The only exception was the "flesh consistency" trait, for which 0 denoted coarse texture, while 100 related to fine/buttery flesh. The gathered data was then transposed to numeric values considering the whole scale to be 10 subjective units. The data was collected through the computerised data collecting system "ANALSENT NT" (Caret, Numerical Systems, Poland) developed at the Polish Academy of Sciences, Warsaw, Poland.

\section{Statistical analysis}

The data was elaborated statistically using the STATISTICA 10.0 software package (Stat Soft Inc., Tulsa, USA). As a measure of the quality traits variation, the standard deviation calculated for means from seasons' repetitions was determined. To check the relation between the instrumental measurement of firmness and sensory attributes a regression method was used and the correlation coefficients were calculated. To illustrate trends of 
softening and sensory attribute changes during the ripening process the means and error charts for each cultivar and storage conditions were prepared. For each set of raw data (cultivar $\times$ storage conditions) an individual trendline was fitted using linear regression: a distance-weighted least squares smoothing procedure, negative exponentially-weighted procedure or polynomial curve, depending on visual assessment. The sensory profiling data was analysed by the multivariate Principal Component Analysis (PCA) on standardised mean data obtained as averages for the best combinations (the highest score for the overall quality) gathered in successive seasons for cultivars and storage conditions. The recommended ripening time for particular cultivar stored at given conditions was determined as minmax range for the set of the best combinations obtained during the successive seasons. Referring to the range of the highest sensory appraisal for each cultivar and storage conditions the level of optimal firmness and soluble solids content was estimated.

\section{RESULTS AND DISCUSSION}

\section{Quality characteristic at harvest}

The maturity and quality characteristics of the examined fruits at harvest are given in Table 3 . The data obtained indicates that pears were harvested at a maturity stage acceptable for storage. If one related the values of Streif' Index to 'Conference' pears (used as a standard), they were at an acceptable level. According to Höehn et al. (1996) 'Conference' fruits should be harvested, when Streif maturity index is in the range of 1.1-0.8, and should end when an index is not lower than 0.54. For the same cultivar Johnson and Luton (1996) recommended an optimal harvesting date (OHD) 0.8, however, they indicated that delayed picking should be encouraged in order to maximise quality (size and soluble solids content), especially considerably later for air storage than for CA. Considering that the planned storage period did not exceed 10 weeks in normal atmosphere and 16 weeks in CA when dealing with new cultivars, it was preferable to pick them at more advanced maturity stage. Only two cultivars 'Concorde' and 'Xenia' had maturity index 0.49, which is still acceptable for short term storage.

The summer cultivars generally had much lower soluble solids content than the late season ones. Of the late ripening ones an exception was 'Erika', which also belongs to a group of low soluble solids cultivars. The highest Brix content close to $14 \%$ had 'Concorde' and 'Verdi', however, the first one was the lowest in the content of acids and 'Verdi' the second most abundant. Considering the above, the proportion of soluble solids to acidity in these cultivars was respectively 88 and 38 . All this indicates that in reference to cultivar characteristics, the material investigated was much diversified.

Table 3. The quality characteristics of pears at harvest. Means and standard deviations for seasons 2008-2011

\begin{tabular}{lcccccc}
\hline \multicolumn{1}{c}{ Cultivar } & $\begin{array}{c}\text { Starch In- } \\
\text { dex }(1-10)\end{array}$ & Firmness (N) & $\begin{array}{c}\text { Soluble sol- } \\
\text { ids }\left({ }^{\circ} \text { Brix }\right)\end{array}$ & $\begin{array}{c}\text { Titratable acidity } \\
\text { as citric acid }(\%)\end{array}$ & $\begin{array}{c}\text { Maturity Index } \\
\text { acc. to Streif }\end{array}$ & $\begin{array}{c}\text { Soluble } \\
\text { solids/acidity }\end{array}$ \\
\hline 'Clapp's Fav.' & $\mathbf{7 . 6} \pm \mathbf{1 . 3 3}$ & $\mathbf{6 2 . 1} \pm \mathbf{1 1 . 6 7}$ & $\mathbf{1 0 . 0} \pm \mathbf{0 , 3 3}$ & $\mathbf{0 . 2 5 5} \pm \mathbf{0 . 0 5 5}$ & $\mathbf{0 . 8 5} \pm \mathbf{0 . 2 7 3}$ & $\mathbf{3 9}$ \\
\hline 'Alfa' & $9.3 \pm 0.56$ & $56.0 \pm 16.48$ & $10.1 \pm 0,49$ & $0.288 \pm 0.059$ & $0.60 \pm 0.203$ & 35 \\
'Radana' & $8.5 \pm 1.11$ & $57.8 \pm 12.69$ & $9.6 \pm 0,49$ & $0.299 \pm 0.059$ & $0.74 \pm 0.243$ & 32 \\
\hline 'Conference' & $\mathbf{7 . 3} \pm \mathbf{1 . 6 1}$ & $\mathbf{6 4 . 5} \pm \mathbf{5 . 6 2}$ & $\mathbf{1 1 . 8} \pm \mathbf{0 . 8 4}$ & $\mathbf{0 . 1 8 5} \pm \mathbf{0 . 0 5 0}$ & $\mathbf{0 . 7 8} \pm \mathbf{0 . 1 6 7}$ & $\mathbf{6 4}$ \\
\hline 'Hortensia' & $8.6 \pm 0.39$ & $61.2 \pm 10.76$ & $12.2 \pm 1.25$ & $0.442 \pm 0.103$ & $0.58 \pm 0.096$ & 28 \\
'Dicolor' & $8.0 \pm 0.55$ & $55.4 \pm 6.24$ & $13.0 \pm 0.52$ & $0.194 \pm 0.022$ & $0.54 \pm 0.060$ & 67 \\
'Concorde' & $8.7 \pm 0.97$ & $57.9 \pm 4.16$ & $13.8 \pm 1.09$ & $0.156 \pm 0.021$ & $0.49 \pm 0.056$ & 88 \\
'Uta' & $8.3 \pm 0.54$ & $72.2 \pm 12.82$ & $12.4 \pm 0.63$ & $0.250 \pm 0.053$ & $0.70 \pm 0.117$ & 50 \\
'Xenia' & $9.1 \pm 0.15$ & $55.3 \pm 7.18$ & $12.4 \pm 1.47$ & $0.208 \pm 0.015$ & $0.49 \pm 0.093$ & 60 \\
'Verdi'* & $9.1 \pm 0.41$ & $61.0 \pm 6.81$ & $13.8 \pm 0.80$ & $0.366 \pm 0.049$ & $0.52 \pm 0.078$ & 38 \\
'Erika'* & $8.0 \pm 1.36$ & $58.2 \pm 4.02$ & $10.6 \pm 0.21$ & $0.355 \pm 0.034$ & $0.70 \pm 0.154$ & 30 \\
\hline
\end{tabular}

*investigated in the seasons of 2009-2011 


\section{Ripening behaviour of the investigated cultivars}

Among different quality attributes fruit firmness has been the most important indicator of the stage of ripeness both from commercial point of view and sensory appraisal. It is obvious that fruit must be harvested firm enough to allow handling and grading as well as during marketing be acceptable in eating quality. As shown in the Table 3, average fruit firmness after picking was between $55 \mathrm{~N}$ ('Dicolor' and 'Xenia') and $72 \mathrm{~N}$ ('Uta'). During storage, there was some decrease of firmness; however, drastic changes in firmness occurred during ripening at room temperature. The dynamic of firmness changes during fruit ripening at $18{ }^{\circ} \mathrm{C}$ is illustrated in Fig. 1 (summer cultivars) and Fig. 2 (late cultivars). The changes depended on several factors: cultivar, storage conditions and length of storage. For some cultivars, changes in firmness during ripening followed the same tendency irrespectively of the storage conditions - an example is 'Conference', 'Hortensia' and also 'Xenia' and 'Erika'. Different ripening behaviour is manifested for 'Concorde' and 'Verdi'. For these two cultivars storage for 16 weeks at CA resulted in a significantly lower firmness during ripening up to about a week, than storage for 8 weeks at NA. Irrespectively of this, all investigated cultivars ripened correctly and the fruit softened up, however, at different rate. Among the summer cultivars the faster ripening rate was manifested for 'Clapp's Favorite' and the slowest for 'Radana'. For late cultivars, the slowest rate of ripening was noted for 'Dicolor' and the fastest for 'Erika' and 'Uta'. Decrease in fruit firmness of some fall/winter cultivars was faster when they were stored under normal atmosphere than of those stored in CA. However, for all investigated cultivars, 'Dicolor' was an exception, with the extension of ripening time, the rate of ripening was clearly slowing down. After five days of ripening firmness of summer pears was in the range of $10 \mathrm{~N}$ for 'Clapp's Favorite' and $45 \mathrm{~N}$ for 'Radana', whereas for the second group of cultivars, it was in the range of $12 \mathrm{~N}$ for 'Conference' and $45 \mathrm{~N}$ for 'Erika'. In conclusion it may be said that some fast ripening cultivars have obviously shorter shelf-life on the contrary to the slow ripening cultivars, which are predisposed for long shelf-life.
Simultaneously as well as a decrease of firmness several other changes in fruit aroma, taste and texture also occurred, all of which could be considered as crucial, when perceived by the potential consumers (Tijskens 2000). In our studies, the most visible changes during ripening time occurred in flesh consistency (Figs. $3 \& 4$ ) and their dynamics depended on cultivar and storage conditions. Majority of the investigated cultivars were able to develop distinctly buttery flesh consistency (up to 8 points at 0-10 points scale). The only exception was 'Erika', for which even after 10 days of ripening the flesh consistency was scored only 6 points (Fig. 4).

According to Płocharski and Konopacka (1999), the sensory quality of pear texture primarily depends on fruit firmness. The correlation coefficients between firmness and flesh consistency calculated for the investigated cultivars were very high and varied between -0.81 and -0.91 . An exception was 'Alfa', for which it was only -0.70 but still significant, although changes pattern depended on storage conditions. The flesh consistency of 'Alfa' fruits stored 6 weeks at $2.5^{\circ} \mathrm{C}$ in normal atmosphere did not change much during ripening period. This was rather surprising considering that its firmness changes were following a general tendency, it is a regular drop during ripening. Apart from the later mentioned 'Alfa' cases, it may be concluded that in general fruit firmness measured by objective method quite well reflects changes in fruit consistency and its practical significance is greater than generally assumed.

In Figures 5 and 6, the changes in characteristic pear flesh aroma sensation evaluated by sensory panel are presented. Generally, the extension of the ripening time resulted in improved aroma both for fruit stored in NA and CA, however, for 'Xenia' development of aroma of the fruits stored in CA was delayed compared to those stored in normal atmosphere. The most dynamically pear aroma development was observed for standard cultivar 'Conference'. Quite similar patterns were observed for 'Xenia', 'Concorde', 'Uta' and 'Erika'. For 'Hortensia', 'Verdi' and 'Dicolor', the trendlines of aroma development have much more flat course, that means they are characterised with more stable aroma intensity during longer period of the shelf-life. Atypical 
aroma development was observed for 'Radana' fruits stored 6 weeks at $2.5^{\circ} \mathrm{C}$. There was no increase of aroma over the whole ripening period, which, as it seems, had negative effect on overall quality of the fruit (Fig. 7). Beside typical pear aroma members of the sensory panel were also esti- mating other possible aroma characteristics: sour aroma, sweet aroma, grass aroma and off aroma. Out of this, only sweet aroma may have some significance being clearly distinguished (often scored above 2 points). Grass aroma and off aroma had negligible effect on perception of fruit quality.
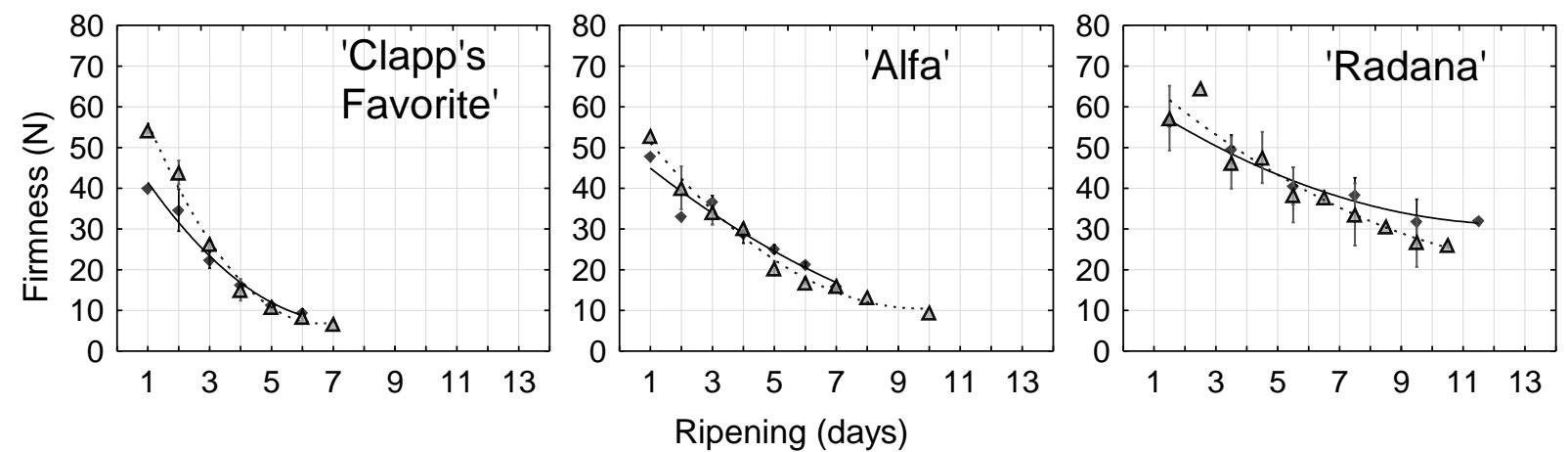

\$ 6 weeks at temperature $2.5^{\circ} \mathrm{C} ; \quad \overline{\underline{ }} 10$ weeks at temperature $-0.5^{\circ} \mathrm{C} ;$ means $+/$ - std error

Fig. 1. Dynamics of summer cultivars softening subjected to ripening at $18{ }^{\circ} \mathrm{C}$ after storage at $2.5{ }^{\circ} \mathrm{C}$ for 6 weeks or 10 weeks at $-0.5^{\circ} \mathrm{C}$ at normal atmosphere
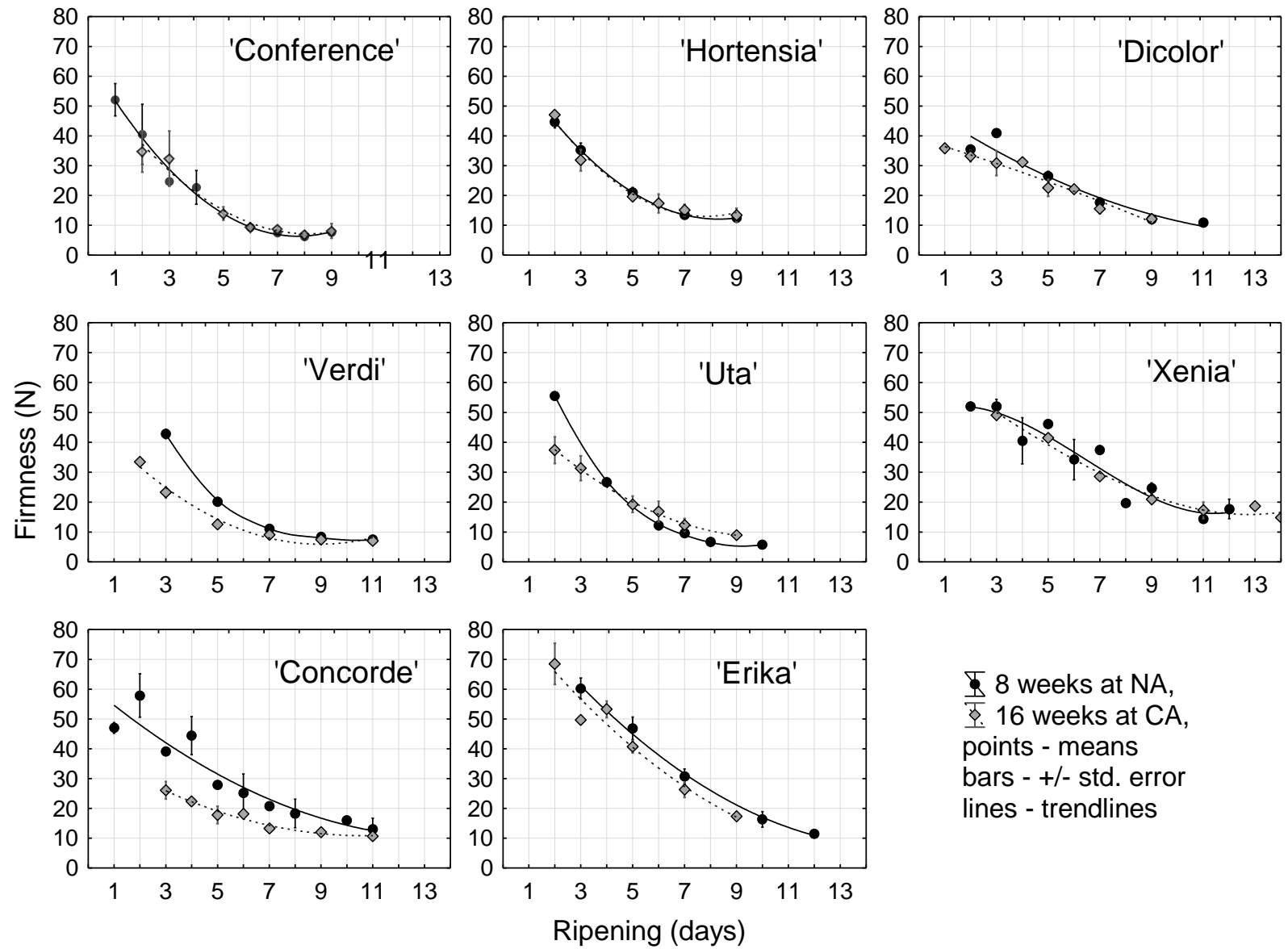

Fig. 2. Dynamics of softening of late pear cultivars subjected to ripening at $18{ }^{\circ} \mathrm{C}$ after storage at $-0.5^{\circ} \mathrm{C}$ under normal atmosphere for 8 weeks or for 16 weeks at CA 

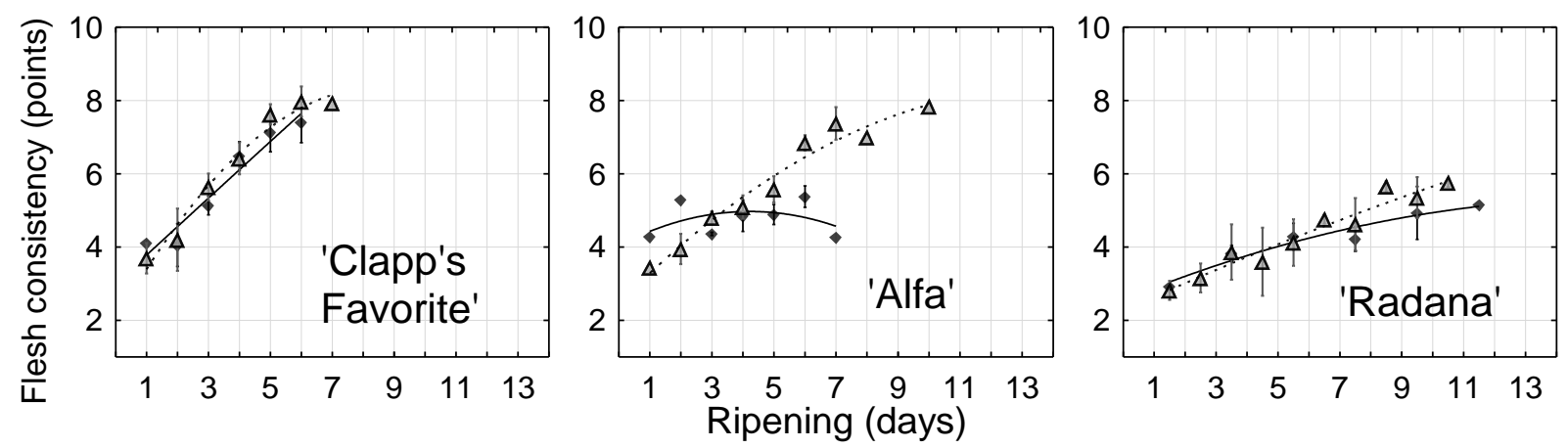

․ 6 weeks at temperature $2.5^{\circ} \mathrm{C}$; 포 10 weeks at temperature $-0.5^{\circ} \mathrm{C} ;$ means $+/$ - std err.

Fig. 3. Flesh consistency ( 0 - coarse, 10 - fine buttery) of summer pear cultivars subjected to ripening at $18{ }^{\circ} \mathrm{C}$ after storage at $2.5^{\circ} \mathrm{C}$ for 6 weeks or 10 weeks at $-0.5^{\circ} \mathrm{C}$ at normal atmosphere
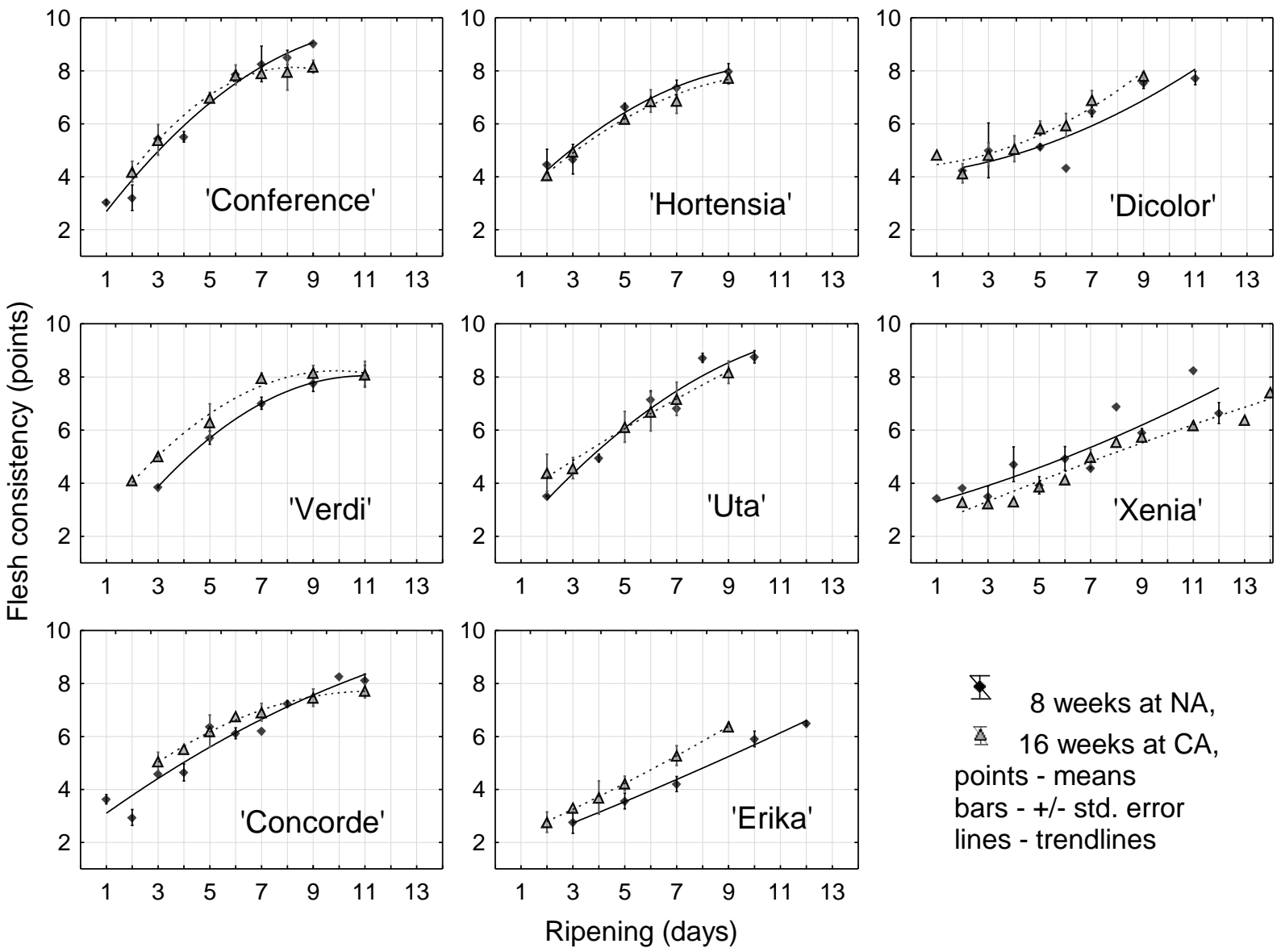

Fig. 4. Flesh consistency ( 0 - coarse, 10 - fine buttery) of late pear cultivars subjected to ripening at $18{ }^{\circ} \mathrm{C}$ after storage at $-0.5{ }^{\circ} \mathrm{C}$ under normal atmosphere for 8 weeks or for 16 weeks at $\mathrm{CA}$ 

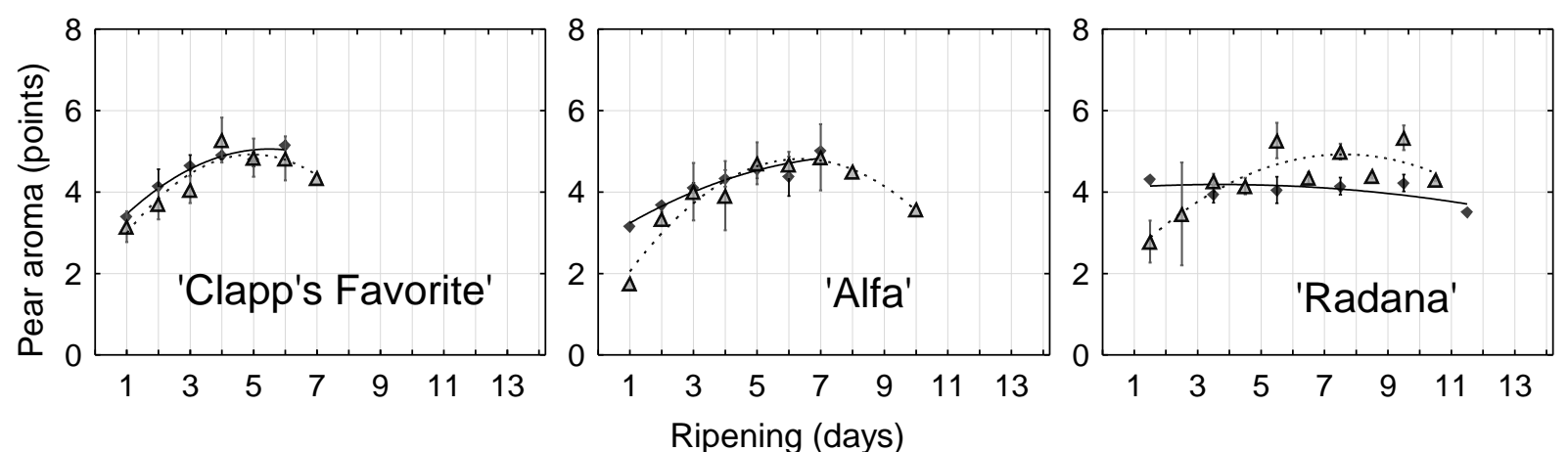

6 weeks at temperature $2.5^{\circ} \mathrm{C}$

쪼 10 weeks at temperature $-0.5^{\circ} \mathrm{C} ;$ means $+/$ - std error

Fig. 5. Pear aroma ( 0 - unnoticeable, 10 - very intensive) of summer pear cultivars subjected to ripening at $18{ }^{\circ} \mathrm{C}$ after storage at $2.5^{\circ} \mathrm{C}$ for 6 weeks or 10 weeks at $-0.5^{\circ} \mathrm{C}$ at normal atmosphere
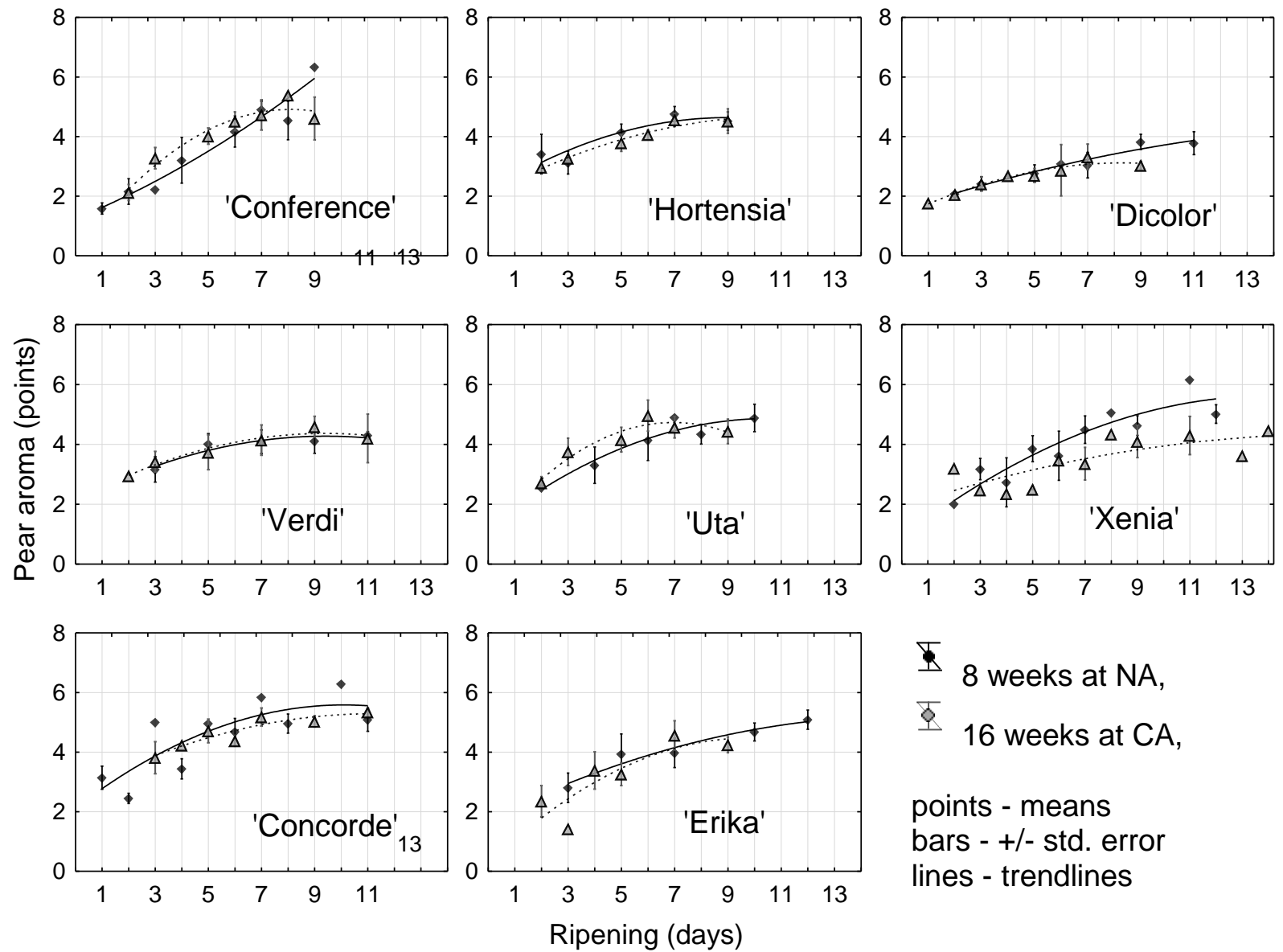

bars - +/- std. error

Ripening (days)

Fig. 6. Pear aroma ( 0 - unnoticeable, 10 - very intensive $)$ of late pear cultivars subjected to ripening at $18^{\circ} \mathrm{C}$ after storage at $-0.5{ }^{\circ} \mathrm{C}$ under normal atmosphere for 8 weeks or for 16 weeks at CA

Changes of the overall sensory appreciation during pear ripening

As it was expected the ripening length significantly influenced overall eating quality, which was illustrated in Figures 7 and 8. For most of the investigated cultivars, the local extreme on the trendlines fitted to the experimental data can be distinguished, that confirm the necessity of precise planning of 
ripening time individually for cultivar and storage conditions. What is more, the overall quality of pears depended very much on cultivar characteristics. Data on Figures 7 and 8 indicate that some cultivars irrespectively of the ripening period were scored much higher than the others. For example 'Xenia' at its optimum ripening stage irrespectively of the storage atmosphere was scored above 6 points in 10 points scale. Highly appreciated was also 'Concorde'. The lowest scores, no more than 4.5 points received 'Alfa'. The standard cultivars 'Clapp's Favorite' and 'Conference' were judged as intermediate in quality, receiving 5-5.5 points. Of the new cultivars higher scores than the late reference cultivar received also 'Verdi', 'Hortensia' and 'Dicolor'. The picture of overall quality to some degree depended also on storage conditions. 'Concorde' fruits were scored higher after being stored in the controlled atmosphere, compared to storage in NA. Positive effect of storage at CA may be noticed for 'Dicolor', 'Verdi' and 'Uta', but only at the beginning of the ripening period (usually up to 3 days). The maximum overall quality was achievable for summer cultivars after 3 to 4 days, whereas for winter cultivars it usually took slightly longer, particularly for fruit stored only 8 weeks at NA. Quite specific cultivar in respect to ripening among summer cultivars was 'Radana' and among winter ones 'Xenia'. It is evident that for 'Radana' the most preferable from the quality point of view is storage at $-0.5^{\circ} \mathrm{C}$ and extension of the ripening period up to 10 days. Storage at $2.5^{\circ} \mathrm{C}$ for 6 weeks resulted in a rapid decrease of quality during successive days of ripening. On the contrary, 'Xenia' was highly scored irrespectively of storage conditions and extension of ripening resulted in improved overall quality up to 12 days. It may then be concluded that beside 'Concorde' this cultivar is the most perspective from the point of overall quality and extended shelf-life during marketing. The obtained results confirmed the observation of Pasquariello et al. (2013) that behaviour of ripening of pears during storage depends on cultivar.

Besides the length of ripening time and storage conditions for given cultivar also other factors might influence its overall sensory appreciation. Among others, the seasonal variations in soluble solids content for investigated cultivars are worth mentioning. The data in Table 4 illustrated the averages of soluble solids contents in stored fruit in successive seasons. For most cultivars more favourable for soluble solids accumulation was the seasons 2008 and 2010. According to Kappel et al. (1995) an ideal pear should have soluble solids above $14 \%$ with total acidity $\approx 180 \mathrm{mg}$ malic acid/100 ml juice. Considering the above, it may be said that none of the summer cultivars at the time of sensory testing fulfilled this requirement. Out of late cultivars only 'Concorde' and 'Verdi' could be qualified. In some seasons also 'Xenia', 'Hortensia', 'Uta' and 'Dicolor' were characterised by soluble solids above $14 \%$, however, observed for these cultivars tendency to seasonal variation in chemical composition can impact their expected equality appreciation.

\section{Quality characteristic of highly scored combina- tions}

To be able to recommend an optimum ripening length for particular cultivars and storage variants for each of investigated seasons the best combinations distinguished by the highest overall quality score were selected. In Table 5, the average values of parameters characterised the investigated cultivars in their optimum stage of ripening are gathered. The exception was the ripening time needed for obtaining the optimum stage of ripening, where instead of an average, the range of days were given. The data in Table 5 summarised the observation described in previous sections and confirmed that each tested cultivar needs an individual strategy during storage and ripening to be able to develop their individual attributes. As concerns the overall sensory quality that could be taken as an indicator of potential consumer appreciation of the fruit at the market, 'Concorde' and 'Xenia' seems to be the most promising as irrespectively of storage variant, in their ripening optimum, they were scored over 6 at 0 10 points scale. 'Hortensia', 'Dicolor' and 'Verdi' were assessed as slightly more attractive than standard 'Conference' that gives them status of fruits of moderate quality. Unfortunately, neither 'Uta' nor 'Erika', like the new summer cultivars, probably would not fulfil sensory expectations of potential consumers. 

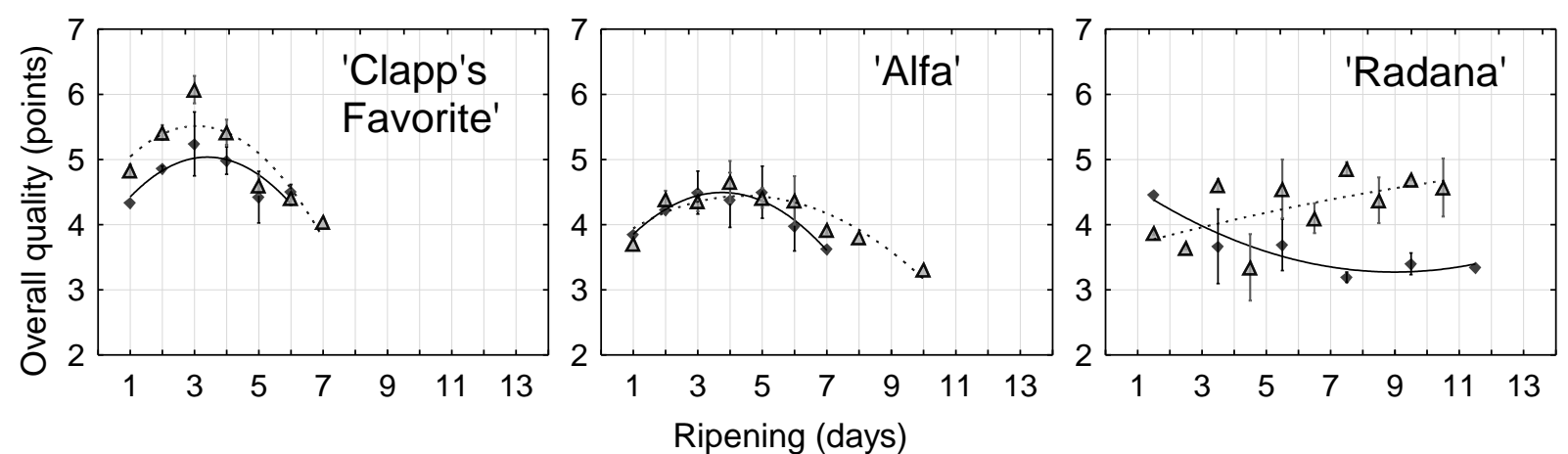

6 weeks at temperature $2.5^{\circ} \mathrm{C}$;

포 10 weeks at temperature $-0.5^{\circ} \mathrm{C}$;

means + / std. errors

Fig. 7. Overall eating quality $(0-$ poor, $10-$ high $)$ of summer pear cultivars subjected to ripening at $18{ }^{\circ} \mathrm{C}$ after storage at $2.5^{\circ} \mathrm{C}$ at normal atmosphere for 6 weeks or 10 weeks at $-0.5^{\circ} \mathrm{C}$ )
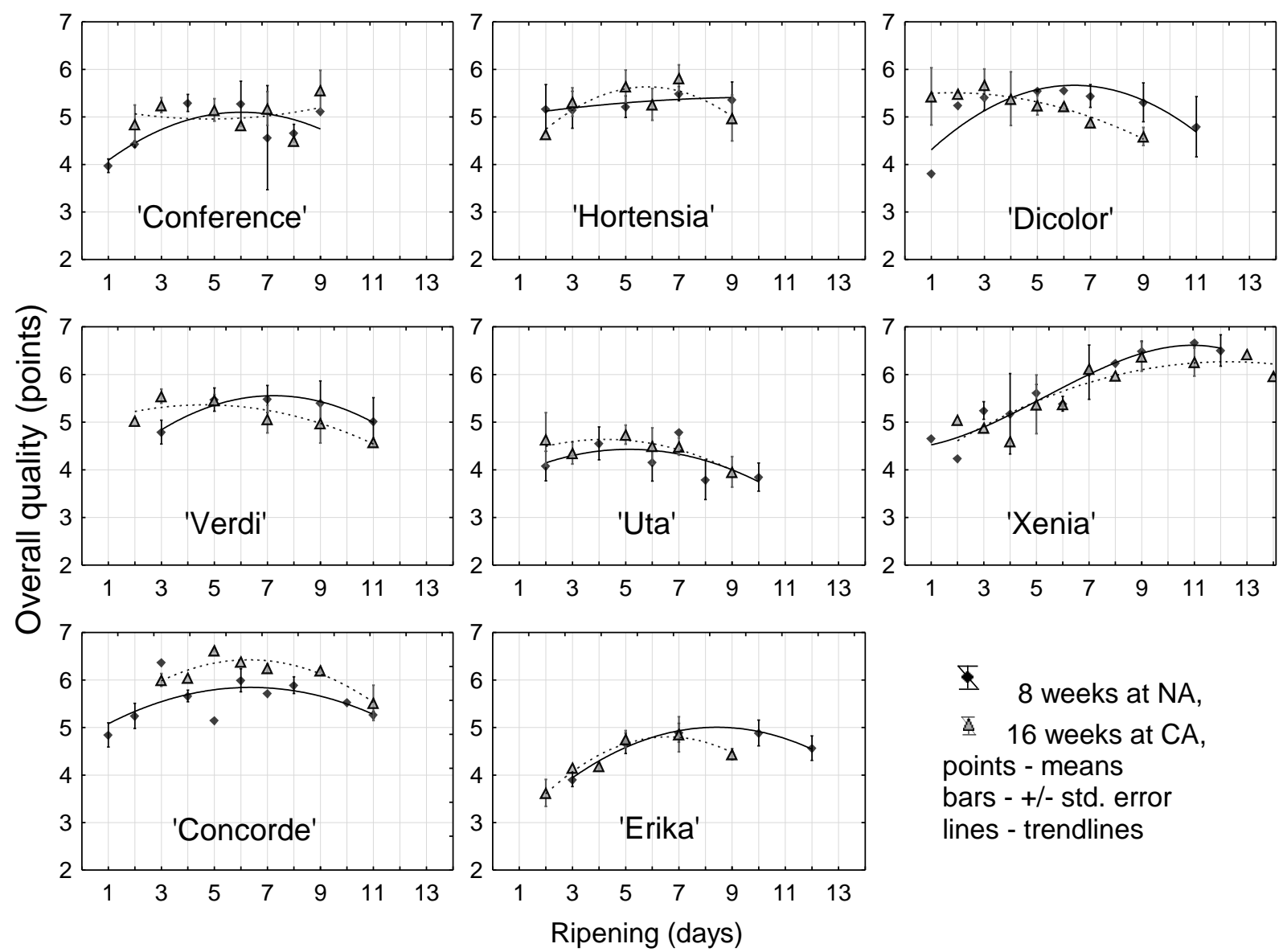

\section{\$ 8 weeks at NA,}

ㅍ 16 weeks at $\mathrm{CA}$,

points - means

bars - +/- std. error

lines - trendlines

Fig. 8. Overall eating quality ( 0 - poor, 10 - high) of late pear cultivars subjected to ripening at $18{ }^{\circ} \mathrm{C}$ after storage at $-0.5^{\circ} \mathrm{C}$ under normal atmosphere for 8 weeks or for 16 weeks at $\mathrm{CA}$ 
Table 4. Soluble solids ( ${ }^{\circ}$ Brix) content of stored pear fruits. Means and standard deviations calculated for all combinations tested in successive years of the experiment

\begin{tabular}{lcrrrc}
\hline \multicolumn{1}{c}{ Cultivar } & 2008 & \multicolumn{1}{c}{2009} & \multicolumn{1}{c}{2010} & \multicolumn{1}{c}{2011} & Average \\
\hline 'Clapp's Favorite & $\mathbf{1 1 . 4} \pm \mathbf{0 . 4 4}$ & $\mathbf{1 1 . 2} \pm \mathbf{0 . 3 5}$ & $\mathbf{1 1 . 3} \pm \mathbf{0 . 2 7}$ & $\mathbf{1 1 . 6} \pm \mathbf{0 . 3 4}$ & $\mathbf{1 1 . 4}$ \\
\hline 'Alfa' & $11.5 \pm 0.34$ & $10.6 \pm 0.41$ & $10.5 \pm 0.19$ & $10.5 \pm 0.36$ & 10.8 \\
\hline 'Radana' & $10.7 \pm 0.32$ & $9.9 \pm 0.45$ & $9.9 \pm 0.54$ & $10.8 \pm 0.31$ & 10.3 \\
\hline 'Conference' & $\mathbf{1 5 . 4} \pm \mathbf{0 . 5 3}$ & $\mathbf{1 2 . 4} \pm \mathbf{0 . 5 3}$ & $\mathbf{1 3 . 9} \pm \mathbf{0 . 3 2}$ & $\mathbf{1 2 . 7} \pm \mathbf{0 . 3 1}$ & $\mathbf{1 3 . 6}$ \\
\hline 'Hortensia' & $16.0 \pm 0.72$ & $13.2 \pm 0.51$ & $13.2 \pm 0.35$ & $12.1 \pm 0.42$ & 13.6 \\
\hline 'Dicolor' & $13.7 \pm 0.64$ & $14.7 \pm 0.47$ & $13.7 \pm 0.51$ & $14.5 \pm 0.26$ & 14.2 \\
\hline 'Concorde' & $15.3 \pm 0.66$ & $14.2 \pm 0.39$ & $15.6 \pm 0.25$ & $15.2 \pm 0.64$ & 15.1 \\
\hline 'Uta' & $14.4 \pm 0.37$ & $13.1 \pm 0.25$ & $14.3 \pm 0.37$ & $13.9 \pm 0.64$ & 13.9 \\
\hline 'Xenia' & $16.3 \pm 0.25$ & $13.3 \pm 0.56$ & $14.3 \pm 0.24$ & $12.5 \pm 0.40$ & 14.1 \\
\hline 'Verdi' & - & $14.6 \pm 0.38$ & $14.4 \pm 0.34$ & $14.4 \pm 0.33$ & 14.5 \\
\hline 'Erika' & - & $12.0 \pm 0.34$ & $13.3 \pm 0.39$ & $13.2 \pm 0.53$ & 12.8 \\
\hline
\end{tabular}

Table 5. Overall sensory quality of pears (means for the seasons $2008-2010$ ), length of ripening at $18{ }^{\circ} \mathrm{C}$ after storage and respective mean firmness and soluble solids \pm the standard deviations

\begin{tabular}{|c|c|c|c|c|c|c|c|c|}
\hline & $\begin{array}{c}\text { Overall } \\
\text { quality } \\
\text { (points) }\end{array}$ & $\begin{array}{l}\text { Ripening } \\
\text { length (days' } \\
\text { range) }\end{array}$ & $\begin{array}{l}\text { Firmness } \\
(\mathrm{N})\end{array}$ & $\begin{array}{c}\text { Soluble } \\
\text { solids } \\
\left({ }^{\circ} \text { Brix }\right)\end{array}$ & $\begin{array}{l}\text { Overall } \\
\text { quality } \\
\text { (points) }\end{array}$ & $\begin{array}{c}\text { Ripening } \\
\text { length (days' } \\
\text { range) }\end{array}$ & $\begin{array}{l}\text { Firmness } \\
(\mathrm{N})\end{array}$ & $\begin{array}{l}\text { Soluble } \\
\text { solids } \\
\left({ }^{\circ} \text { Brix }\right)\end{array}$ \\
\hline $\begin{array}{l}\text { Summer } \\
\text { cultivars }\end{array}$ & \multicolumn{4}{|c|}{ Temperature $2.5^{\circ} \mathrm{C}(6$ weeks $)$} & \multicolumn{4}{|c|}{ Temperature $-0.5{ }^{\circ} \mathrm{C}(10$ weeks $)$} \\
\hline 'Clapp's F.' & $5.4 \pm 0.6$ & $2-4$ & $24 \pm 7$ & $11.1 \pm 0.2$ & $6.0 \pm 0.5$ & $3-3$ & $27 \pm 2$ & $11.5 \pm 0.2$ \\
\hline 'Alfa' & $4.6 \pm 0.5$ & $2-5$ & $28 \pm 5$ & $10.4 \pm 0.2$ & $4.8 \pm 0.6$ & $3-6$ & $25 \pm 7$ & $10.9 \pm 0.6$ \\
\hline 'Radana' & $4.3 \pm 0.7$ & $2-6$ & $48 \pm 7$ & $9.8 \pm 1.0$ & $4.7 \pm 0.4$ & $8-11$ & $30 \pm 8$ & $10.6 \pm 0.2$ \\
\hline Late cultivars & \multicolumn{4}{|c|}{$\mathrm{NA}$, temperature $-0.5^{\circ} \mathrm{C},(8$ weeks $)$} & \multicolumn{4}{|c|}{$\mathrm{CA}$, temperature $-0.5^{\circ} \mathrm{C},(16$ weeks $)$} \\
\hline 'Conference' & $5.6 \pm 0.6$ & $4-7$ & $13 \pm 9$ & $13.9 \pm 1.3$ & $5.4 \pm 0.4$ & $3-7$ & $14 \pm 9$ & $13.6 \pm 1.2$ \\
\hline 'Hortensia' & $6.1 \pm 0.9$ & $2-9$ & $17 \pm 9$ & $13.9 \pm 1.1$ & $5.9 \pm 0.5$ & $5-7$ & $17 \pm 2$ & $12.9 \pm 0.9$ \\
\hline 'Dicolor' & $5.7 \pm 0.2$ & $3-7$ & $21 \pm 8$ & $14.5 \pm 0.4$ & $5.9 \pm 0.5$ & $2-6$ & $28 \pm 4$ & $14.3 \pm 0.6$ \\
\hline 'Concorde' & $6.2 \pm 0.4$ & $3-8$ & $27 \pm 13$ & $15.3 \pm 0.8$ & $6.5 \pm 0.1$ & $5-6$ & $18 \pm 3$ & $15.0 \pm 0.6$ \\
\hline 'Uta' & $4.8 \pm 0.4$ & $2-6$ & $32 \pm 22$ & $13.6 \pm 0.8$ & $5.1 \pm 0.2$ & $2-7$ & $22 \pm 9$ & $14.0 \pm 0.3$ \\
\hline 'Xenia' & $6.7 \pm 0.4$ & $9-12$ & $21 \pm 5$ & $14.3 \pm 1.5$ & $6.4 \pm 0.4$ & $8-13$ & $22 \pm 9$ & $13.8 \pm 1.1$ \\
\hline ‘Verdi'* & $5.7 \pm 0.5$ & $5-9$ & $13 \pm 5$ & $14.6 \pm 0.2$ & $5.6 \pm 0.3$ & $5-9$ & $11 \pm 4$ & $14.7 \pm 0.5$ \\
\hline 'Erika'* & $5.0 \pm 0.4$ & $7-10$ & $22 \pm 10$ & $13.3 \pm 0.6$ & $5.0 \pm 0.5$ & $5-7$ & $29 \pm 10$ & $13.1 \pm 0.9$ \\
\hline
\end{tabular}

* investigated in the seasons of 2009-2011

The more detailed sensory characteristic of the investigated pear cultivars in their optimal stage of ripening is shown in Figure 9 in the form of a 'quality map'. The space created by the first two principle components (PC1 and PC2) combined accounts for $77.5 \%$ of the total variation in the sensory perception of pear fruits. Most of the vectors representing attributes connected with texture properties (crispness, hardness, crunchiness, flesh consistency, juiciness) were placed along the horizontal axis, which means that texture perception is predominant with regards to sensory characteristics (PCA $1=60.6 \%$ ). The high overall texture score is a resultant of some optimum characteristics and the vector is placed between region representing poorly ripen fruits (vectors illustrated high sensation of hardness, crunchiness, crispness) and vectors representing something overripe fruits (high sensation of juiciness and flesh buttery consistency). Finally, the overall texture vector is placed perpendicularly to the previously mentioned texture vectors and is more related to taste and aroma attributes arranged closer to the 


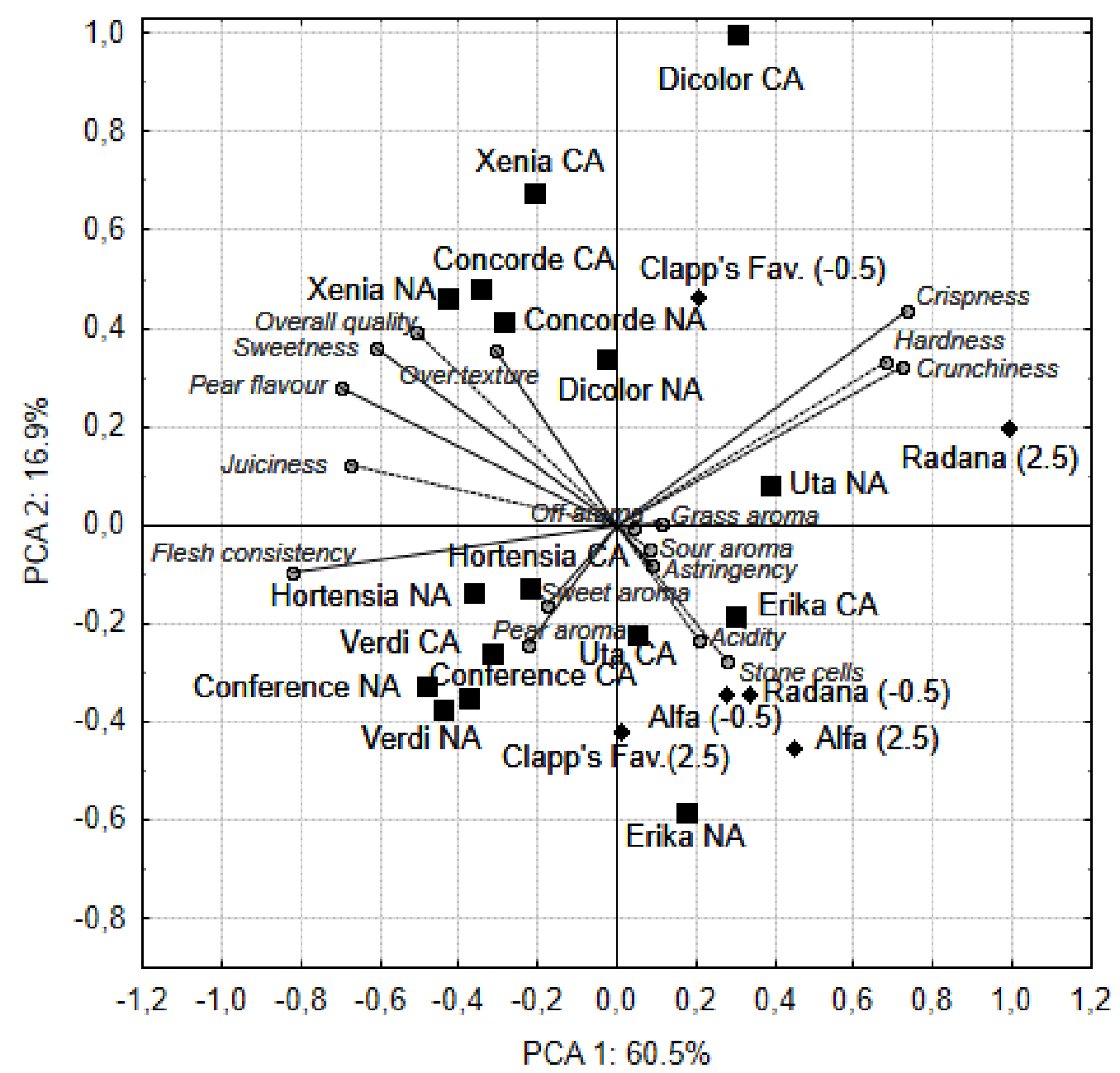

Fig. 9. PCA projection of the differences and similarities in sensory characteristic of new pear cultivars stored at certain storage conditions. Points represent: $(\diamond)$ summer cultivars stored for 6 weeks at $2.5^{\circ} \mathrm{C}$ or for 10 weeks at $-0.5^{\circ} \mathrm{C}$, squares $(\mathbf{\square})$ depict winter ones stored for 8 weeks at NA or for 16 weeks at CA. Vectors illustrate the evaluated attributes of the sensory characteristic. Means for the best combinations obtained within 2008-2011 seasons

PCA 2 component that contributed to a variation of $16.9 \%$. The relationships between the orientations of the vectors of a particular sensory attribute and the points characterised by each cultivars stored at certain temperature or atmosphere allowed us to anticipate the general eating quality characteristic of the investigated cultivars, that might be expected after certain storage conditions. The longer the vector displaying particular sensory attributes on the PCA graph, the higher the diversification of this trait was noticed within the investigated sample. Points placed close to a particular vector are characterised predominantly with this attribute. Further points placed close together are similar when comparing their eating quality characteristics.
As we can see, the points placed closer to the overall quality vector belong to 'Xenia' stored at NA conditions. These fruits, especially in the best possible stage of maturity, were characterised by high sweetness and distinct pear flavour as well as rather juicy flesh. Quite similar characteristic might be related to 'Concorde' fruits stored both at NA and CA conditions. Further 'Xenia' fruits stored at CA, 'Dicolor' stored at NA and 'Clapp's Favorite' stored at temperature $-0.5^{\circ} \mathrm{C}$ could be perceived as having good overall texture, however they were perceived as slightly more crispy and crunchy that probably was connected with their higher firmness related to the best sensory appreciation. The crunchy texture was especially characteristic for 
'Uta' stored at NA, and 'Radana' stored at temperature $+2.5^{\circ} \mathrm{C}$, however these fruits were scored rather low, as points representing them are placed far from the vector of the overall quality. Also 'Radana' stored at temperature $-0.5^{\circ} \mathrm{C}$ as well as 'Erika' and 'Alfa' (irrespectively of storage conditions) were assessed as having low overall quality, but in this case that was connected with strong sensing of stone cells related to distinct acidity and even astringency taste occurred parallel to sweetness deficiency. Among the investigated cultivars, 'Hortensia', 'Verdi' and 'Conference' (both for CA and NA conditions) can be distinguished as a group of moderate overall eating quality, but in their optimum ripening stage characterised by aromatic and clearly buttery flesh. On the contrary, 'Dicolor' fruits stored at CA, placed on the 'quality map' in opposite direction to the latter, are also perceived as having moderate overall eating quality, but they stand out by very low aroma intensity and, rather coarse than buttery flesh consistency. Generally, cultivars belonging to a group able to develop buttery flesh consistency were higher appreciated than that characterised by crunchy texture. According to the presented 'quality map' sweetness, juiciness and buttery flesh consistency are the crucial attributes that impact overall quality assessment. Unfortunately, none of new summer cultivars and only a few late cultivars were able to develop such characteristic during ripening time.

\section{CONCLUSIONS}

1. The obtained data indicates that the ripening behaviours responding to applied storage conditions are highly differentiated between cultivars. Fruit firmness may be considered as a predictor of consumer appreciation for a group of selected cultivars considering all other attributes of quality.

2. Our results confirm that each cultivar, especially the newly introduced ones, need an individual strategy during storage and ripening to be able to maximise their specific sensory attributes to increase potential market value.

3. The overall sensory quality taken as an indicator of potential consumer appreciation of the fruit at the market depends on several factors connected with fruit aroma, texture and taste attributes. As the mostly appreciated attributes - sweetness, juiciness and buttery flesh consistency were identified.

4. The gathered data allow to anticipate that 'Xenia' and 'Concorde' have the biggest chance to fulfil the consumer expectations. The 'Concorde' pear fruits look especially promising as concerns keeping a decent quality during extended shelf-life.

5. Among other investigated cultivars 'Hortensia' and 'Verdi' revealed sensory characteristic similar to the reference cultivar 'Conference' with slightly higher overall quality appreciation. Also in the optimum stage of ripening 'Dicolor' fruits received similar notes for the overall quality, however their flesh was perceived as less aromatic and crunchier.

\section{Acknowledgement}

This study was found by statutory programme of the Research Institute of Horticulture (S 6.1).

\section{REFERENCES}

Błaszczyk J. 2010. Influence of harvest date and storage conditions on the changes of selected qualitative conditions of 'Concorde' pears. J. Fruit Ornam. Plant Res. 18(2): 211-221.

Błaszczyk J. 2011. Influence of harvest date and storage conditions on the quality and storability of new pear cultivars. Wydawnictwo Uniwersytetu Rolniczego, Kraków, 123 p. [in Polish with English abstract]

Błaszczyk J., Buczek M. 2002. Effect of cold storage on the storability of 'Carola' and 'Concorde' pears. Zesz. Nauk. Inst. Sadow. Kwiac 10: 227-233. [In Polish with English abstract]

Höhn E., Dätwyler D., Gasser F. 1996. Maturity indices to predict optimum harvest date for the storage of Conference pears in Switzerland. In: de Jager A., Johnson D., Höhn E. (Eds.), Determination and prediction of optimum harvest date of apples and pears. ECS-EC-EAC, Brussels, Luxembourg, pp. 149-157.

Hardenburg R.E., Watada A.E., Wang C.Y. 1986: The commercial storage of fruits, vegetables, and florist and nursery stocks. U.S. Department of Agriculture, Agriculture Handbook 66.

Johnson D.S., Luton M.T. 1996. Maturity indices to predict optimum harvest date for the storage of Conference pears in the UK. In: de Jager A., Johnson 
D., Höhn E. (Eds.), Determination and prediction of optimum harvest date of apples and pears. ECSEC-EAC, Brussels, Luxembourg, pp. 133-148.

Kappel F., Fisher-Fleming R., Hogue E.J. 1995. Ideal pear sensory attributes and fruit characteristics. HortScience 30(5): 988-993.

Konopacka D., Jesionkowska K., Rutkowski K., Płocharski W., Tomala K. 2006. A comparison of the quality of well known and scab resistant apples in expert and consumer evaluation. Veget. Crops Res. Bull. 65: 185-194.

Ma S.S., Chen P.M. 2003. Storage disorder and ripening behavior of 'Doyenne du Comice' pears in relation to storage conditions. Postharvest Biol. Technol. 28: 281-294. DOI: 10.1016/S0925-5214(02)00179-5

Nosecka B. 2012. Analizy Rynkowe - Rynek Owoców i Warzyw 41. Zakład Ekonomiki Ogrodnictwa IERiG-PIB, Warszawa. [in Polish]

Pasquariello M.S., Rega P., Migliozzi T., Capuano L.R., Scortichini M., Petriccione M. 2013. Effect of cold storage and shelf life on physiological and quality traits of early ripening pear cultivars. Sci. Hortic. 162: 341-350. DOI: 10.1016/j.scienta.2013.08.034.

Pinto A.S., Barreiro G., Fragata A., Combris P, GiraudHeraud E. 2008. Quality attributes of 'Rocha' pear and consumer behaviour: Sensory evaluation and willingness to pay. Acta Hort. 800: 1005-1012.

Predieri S., Gatti E. 2008. Consumer evaluation of 'Abate Fetel' Pears. Acta Hort. 800: 999-1004.

Predieri S., Gatti E. 2009. Effect of cold storage and shelflife on sensory quality and consumer acceptance of "Abate Fetel" pears. Postharvest Biol. Technol. 51: 342-348. DOI: 10.1016/j.postharvbio.2008.09.006.

Płocharski W., Konopacka D. 1999. Relation between mechanical and organoleptical parameters of apples and pears. Acta Hort. 485: 309-317.
Salvador A., Varela P., Fiszman S.M. 2007. Consumer acceptability and shelf life of "Flor de Iinvierno" pears (pyrus communis L.) under different storage conditions. Journal of Sensory Studies, 22:3, 243255. DOI: 10.1111/j.1745-459x.2007.00104.x

Steyn, W.J., Manning, N., Muller, M. Human, J.P. 2011. Physical, sensory and consumer analysis of eating quality and appearance of pear genotypes among South African consumers. Acta Hort. 909: 579-586.

Streif J., Saquet A.A, Xuan H. 2003. CA-related disorders of apples and pears. Acta Hort. 600: 223230.

Sugar D. Postharvest handling of winter pears. 2007. In: Mitcham E.J., Elkins R.B. (Eds.), Pear Production and Handling Manual. University of California, Div. Agric. Natural Resources. Pub. 3483, chapter 4.

Tijskens L.M.M. 2000. Acceptability. In: Shewfeld R.L., Brückner B. (Eds.), Fruit and vegetable quality: an integrated view. Technomic Press, USA, p.125-143.

Wang Y., Sugar D. 2013. Ripening behavior and quality of modified atmosphere packed 'Doyenne du Comice' pears during cold storage and simulated transit. Postharvest Biol. Technol. 81: 51-59. doi:10.1016/j.postharvbio.2013.02.010

Wawrzyńczak A., Rutkowski K.P., Kruczyńska D. 2006. Changes in fruit quality in pears during CA storage. J. Fruit Ornam. Plant Res 18 (suppl.1): 77-83.

Wawrzyńczak A., Rutkowski K.P., Kruczyńska D. 2008a. Fruit quality of some pear cultivars as influenced by storage temperature. Zesz. Nauk. Inst. Sadow. Kwiac. 16: 153-158. [In Polish, with English abstract]

Wawrzyńczak A., Rutkowski K.P., Kruczyńska D. 2008b. Ripening of 'Radana' and 'Conference' pears as influenced by cold storage duration. Acta Hort. 800: 1091- 1097. 